\title{
Pengaruh Keputusan Investasi, Return On Asset (ROA) dan Return On Equity (ROE) Terhadap Nilai Perusahaan Pada Sektor Perbankan Yang Terdaftar di Bursa Efek Indonesia Periode 2010 - 2017
}

\author{
Eka Rahim ${ }^{1)}$ \\ ${ }^{1)}$ dosen Universitas Pamulang, email : dosen01736@unpam.ac.id
}

\section{ARTICLES \\ INFORMATION}

\section{ABSTRACT}

\section{JURNAL SEKURITAS \\ (Saham, Ekonomi, Keuangan dan Investasi ) \\ Vol.3, No.2, Januari 2020 Halaman : $197-207$ \\ () LPPM \& Prodi Manajemen UNVERSITAS PAMULANG \\ ISSN (online) : 2581-2777 ISSN (print) : :2581-2696}

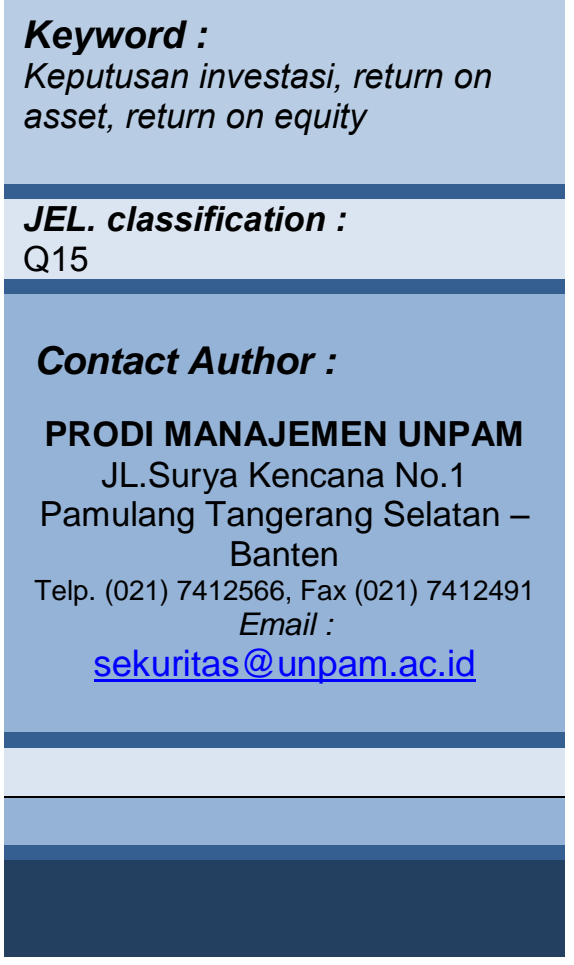

Penelitian ini bertujuan untuk menguji pengaruh keputusan investasi (PER), return on asset (ROA), dan return on equity (ROE) secara parsial dan simultan terhadap nilai perusahaan pada sektor keuangan (Bank) di Bursa Efek Indonesia periode 2010 sampai 2017 .

populasi dalam penelitian ini adalah untuk semua perusahaan bank yang terdaftar di bursa efek indonesia selama 2010-2017. Berdasarkan kriteria tertentu, ada 20 dari 48 perusahaan bank yang cocok dengan sampel. Metode statistik yang digunakan dalam penelitian ini adalah regresi berganda.

Purpose of this study was to know the influence of investment decision (PER) return on asset (ROA) and return on equity (ROE) to the firm value. the study focused on all bank companies listed in Bursa Efek Indonesia during 2010 - 2017.

Population in this study was to all bank companies listed in Bursa Efek Indonesia during 2010 - 2017 . Based on certain criteria, there were 20 of 48 bank companies that matched with the sample. The statistical method used in this study was multiple regression . 


\section{A. PENDAHULUAN}

Perkembangan ekonomi yang sedang tumbuh dan maju tentu saja memicu banyak perusahaan baik yang bergerak di bidang perdagangan, jasa, dan perbankan. Setiap perusahaan pada umumnya harus memiliki tujuan yang sama dengan yang lain, yaitu untuk mendapaí untung besar. Oleh karena itu, untuk mencapai tujuan tersebut, kita memerlukan manajemen yang baik agar perusahaan dapat dikelola dengan baik.

Satu entitas bisnis yang bergerak dalam perdagangan dan jasa adalah perbankan atau bank. Bank adalah badan usaha yang mengumpulkan dana dari publik dalam bentuk setoran dana untuk mendistribusikannya kepada publik dalam bentuk kredit, dan atau bentuk lain untuk meningkatkan kehidupan banyak orang (Undang-Undang No. 10 1998 tentang perbankan).

Menurut Ross et al (2008:54) Nilai perusahaan adalah pencapaian suatu perusahaan sebagai indikator kepercayaan pemegang saham terhadap perusahaan sejak berdirinya perusahaan hingga sekarang. Nilai perusahaan adalah perbandingan nilai pasar dengan nilai buku perusahaan per saham. Sedangkan menurut Sukimi (2012:3) Pemegang saham menilai dengan bersedia membeli saham dengan harga tertentu dengan persepsi dan keyakinan mereka. Nilai suatu perusahaan terkait dengan harga sahamnya juga ditentukan oleh (Sujoko dan Soebiantoro, 2007: 43), menyatakan bahwa nilai perusahaan sebagai persepsi pemegang saham dan sering dikaitkan dengan harga saham.

PER dikenal sebagai salah satu indikator terpenting di pasar modal. PER adalah rasio yang menggambarkan bagaimana laba perusahaan terhadap harga saham (harga saham). Perhitungan rasio PER ini dilakukan dengan membagi harga saham saat ini dengan laba per saham tahunan.

\section{B. KAJIAN LITERATUR}

\section{Pengertian Keputusan Investasi}

Pertumbuhan bagi suatu perusahaan adalah adanya peluang investasi yang tentunya menghasilkan keuntungan bagi perusahaan. Jika ada peluang investasi yang menguntungkan, manajer akan bersaing untuk mengambil kesempatan untuk memaksimalkan perusahaan dan tentu saja pemegang saham. Karena semakin besar peluang investasi yang menguntungkan, banyak yang akan melakukan investasi.

\section{Profitabilitas (ROA)}

Gill, James, O dan Moira Chatton (2008: 47) mengemukakan bahwa profitabilitas adalah hal yang paling penting dalam sebuah bisnis. Kami ingin pengembalian yang lebih baik dari upaya kami sendiri daripada meminjam dari bank atau untuk peluang, dan tentu saja itu sering digunakan untuk membandingkan dua atau lebih perusahaan di industri yang sama.

$$
R O A=\frac{\text { Earning After Tax }}{\text { Total assets }} \times 100 \%
$$




\section{Return On Equity (ROE)}

Membandingkan jumlah antara laba bersih dan ekuitas biasa. Jika semakin tinggi atau nilai persentase berarti kinerja keuangan perusahaan semakin baik. Sehingga dapat dikatakan bahwa bisnis dapat memberikan pengembalian yang menguntungkan.

\section{Nilai Perusahaan}

Menurut Ross et al (2008:54) Nilai Perusahaan adalah pencapaian suatu perusahaan sebagai indikator kepercayaan pemegang saham terhadap perusahaan sejak berdirinya perusahaan hingga sekarang. Nilai perusahaan adalah perbandingan nilai pasar dengan nilai buku perusahaan per saham. Nilai perusahaan terkait dengan harga sahamnya juga ditentukan oleh (Sujoko dan Soebiantoro, 2007: 43). Menyatakan nilai perusahaan sebagai persepsi pemegang saham. Penelitian ini memproksi nilai perusahaan dengan price to book value (PBV) sesuai dengan Rosyita (2008), Nailafuroh (2011), Sukimi (2012), Mardiyati et al (2012 () dan penelitian Kurnia dan Ayuningtyan (2013). digunakan dikonfirmasi dalam price book value (PBV).

\section{METODOLOGI PENELITIAN}

Menurut Effendi (2005:5) Metodologi yang digunakan adalah penelitian penjelasan yang menggunakan pendekatan kuantitatif. Dalam (Umi, Gatot, dan Abrar. 2015) tujuan penelitian untuk menjelaskan hubungan sebab akibat antar variabel melalui pengujian hipotesis, maka data yang diperoleh akan diproses, kemudian akan dianalisis secara kuantitatif dan selanjutnya akan diproses menggunakan program Eviews 7 dan dasar-dasar teori sebelumnya akan dipelajari untuk menjelaskan bagaimana deskripsi dari Objek yang diteliti,

\section{Populasi}

Populasi dalam penelitian ini yaitu perusahaan perbankan yang terdaftar di Bursa Efek Indonesia periode 2010-2014. Adapun populasi yang digunakan adalah 48 perusahaan sektor perbankan yang telah terdaftar di Bursa Efek Indonesia.

\section{Sampel}

Menurut Sugiyono (2010:117) Sampel merupakan bagian dari jumlah dan karakteristik yang dimiliki populasi. Sampel diperoleh dari beberapa objek populasi yang akan diteliti.

\section{A. Cara Pengumpulan Data}

Cara pengumpulan data di dalam penelitian ini yaitu Analisis Kuantitatif. Yaitu menganalisis data yang berkaitan dengan angka-angka yang terkandung dalam laporan keuangan dan dihitung sebagai alat untuk mengukur tingkat pengaruh keputusan investasi, profitabilitas diproksi dengan menggunakan rasio profitabilitas, antara lain: pengembalian aset, dan pengembalian ekuitas terhadap nilai perusahaan.

\section{B. Teknik Penentuan Data}

yang digunakan pada penelitian ini menggunakan regresi data panel. Analisis data panel merupakan kombinasi cross section dan datadata time series. 


\section{HASIL DAN PEMBAHASAN}

\section{Uji Asumsi Klasik}

\section{a) Uji Multikloniearitas}

Menurut (Tony Wijaya, 2011: 121) adalah tes yang digunakan untuk menguji apakah model regresi menemukan hubungan antara variabel independen (independen). Adapun pengambilan multikolinearitas:

Jika VIF> 10, maka Ha diterima (terdapatt multikolinearitas).

Jika VIF $<10$, maka Ha ditolak (tidak ada multiklonieritas).

Dalam Penelitian ini diperoleh nilai VIF seperti pada tabel sebagai berikut :

Hasil Uji Multikloniearitas

Variance Inflation Factors

Date: 03/04/16 Time: 17:19

Sample: 1100

Included observations: 100

\begin{tabular}{llll}
\hline \hline Variable & $\begin{array}{l}\text { Coefficient } \\
\text { Variance }\end{array}$ & $\begin{array}{l}\text { Uncentered } \\
\text { VIF }\end{array}$ & $\begin{array}{l}\text { Centered } \\
\text { VIF }\end{array}$ \\
\hline \hline C & 0.561725 & 2.622880 & NA \\
ROA & 155.8776 & 1.408673 & 1.009852 \\
ROE & 3.982493 & 2.027367 & 1.019885 \\
PER & 0.000308 & 1.202396 & 1.017045 \\
\hline \hline
\end{tabular}

Sumber : Data diolah dengan menggunakan Eviews7

Dari hasil tabel diatas adalah :

1.Pada variabel $X 1$ yaitu keputusan investasi (PER) mempunyai nilai VIF sebanyak $0.009852<10$ maka dapat diartikan bahwa tidak terdapat multiklonieritas .

2. Pada variabel $X 2$ yaitu Return on asset (ROA) mempunyai nilai VIF sebanyak $1.019885<10$ maka dapat diartikan bahwa tidak terdapat multiklonieritas.

3. Pada variabel $X 3$ yaitu Return on equity (ROE ) mempunyai nilai VIF sebanyak $1.019885<10$ maka dapat diartikan bahwa tidak terdapat Multiklonieritas. 


\section{b. Uji Heteroskedastitas}

Bertujuan untuk menguji apakah ada perbedaan yang tidak sama dari residu dari satu pengamatan ke yang lain. Di mana ada kesamaan dalam versi dari satu residu pengamatan ke yang lain, itu adalah homoskedastity.

White Test umumnya digunakan untuk menentukan apakah kesalahan varians adalah homokedastisitas atau heterokedastisitas. Untuk mengetahui keberadaan heteroskedastisitas dengan perangkat lunak Eviews 7, dapat dilihat dari Uji Heteroskedastisitas Umum White (No Cross Term), yang melihat pada probabilitas Obs ". Dibandingkan dengan pengujian hipotesis berikut:

$\mathrm{H}_{0}$ : Kesalahan varians is homoscedasticity

$\mathrm{H}_{1}$ : Varians kesalahan adalah hoteroskedasticity

\section{Uji Heterokedastisitas}

(no cross terms)

Heteroskedasticity Test: White

\begin{tabular}{lrll}
\hline \hline F-statistic & 2.656168 & Prob. F(9,40) & 0.0162 \\
Obs $^{*}$ R-squared & 18.70380 & Prob. Chi-Square(9) & 0.0278 \\
Scaled explained SS 20.63530 & Prob. Chi-Square(9) & 0.0144
\end{tabular}

Sumber : Data diolah dengan menggunakan Eviews7.2

\section{Uji Heteroskedastisitas}

\section{Cross terms}

Heteroskedasticity Test: White

\begin{tabular}{lrll}
\hline \hline F-statistic & 0.962245 & Prob. F(3,46) & 0.4186 \\
Obs*R-squared & 2.952473 & Prob. Chi-Square(3) & 0.3990 \\
Scaled & explained & & \\
SS & 3.257369 & Prob. Chi-Square(3) & 0.3536 \\
& & &
\end{tabular}

Sumber : Data diolah dengan menggunakan Eviews7.2

tabel hasil ujiatas dapat dilihat bahwa Probability Obs "R. hasil yang baik paling adalah dengan syarat lintas 18,70380 dan pengujian whitecrosterms dan nilai yang dihitung hingga 2,952473 $\mathrm{x}_{\text {tabel }}^{2}$ dengan tingkat signifikan $=5 \%$ adalah 7,81473. sebagai $\mathrm{X}^{2}$ dihitung baik untuk kulit putih tidak ada salibpersyaratan ujidan thetest hal salib putih $<\mathrm{X}^{2}$ tabel, , aka dapat disimpulkan bahwa model di atas lulus uji heteroskedastisitas. 


\section{2) Uji Hipotesis}

\section{a. Uji Regresi Linear Berganda}

Digunakan untuk mengetahui seberapa besar pengaruh variabel bebas (PER,ROA,ROE ) baik secara parsial maupun bersama - sama atau simultan terhadap variabel terikat ( Price Book Value) ,sehingga dapat diketahui ketiga variabel bebas tersebut berpengaruh signifikan terhadap nilai perusahaan (PBV).

Hasil Uji Regresi Liniear Berganda

Dependent Variable: PBV

Method: Panel Least Squares

Date: 03/06/16 Time: 16:19

Sample: 20102014

Periods included: 5

Cross-sections included: 20

Total panel (balanced) observations: 100

\begin{tabular}{lcccc}
\hline \hline Variable & \multicolumn{2}{l}{ Coefficient Std. Error } & t-Statistic & Prob. \\
\hline \hline C & 1.507765 & 0.853984 & 1.765567 & 0.0806 \\
PER & 0.052413 & 0.025275 & 2.073670 & 0.0408 \\
ROA & 1.912066 & 0.751385 & 2.544723 & 0.0125 \\
ROE & -0.203046 & 0.100005 & -2.030355 & 0.0451 \\
& & & & \\
\hline \hline R-squared & 0.106208 & Mean dependent var & 2.232400 \\
Adjusted R-squared & 0.078277 & S.D. dependent var & 3.347260 \\
S.E. of regression & 3.213584 & Akaike info criterion & 5.211829 \\
Sum squared resid & 991.4036 & Schwarz criterion & 5.316035 \\
Log likelihood & -256.5914 & Hannan-Quinn criter. & 5.254003 \\
F-statistic & 3.802524 & Durbin-Watson stat & 1.365708 \\
Prob(F-statistic) & 0.012655 & & \\
\hline \hline
\end{tabular}

Sumber : Data diolah dengan menggunakan Eviews 7.2

Model persamaan regresi linier berganda berdasarkan hasil di atas adalah:

$Y=1,507765+0,052413 X 1+1,912066 X 2+-0,203046 X 3$

Interpretasi dari persamaan regresi linier berganda berdasarkan hasil di atas adalah: 
1) Nilai konstan sama dengan 1,507765 , artinya jika keputusan investasi, return on aset, return on equity nilainya yaitu 0 , maka nilai perusahaan adalah 1,507765 .

2) Koefisien regresi keputusan investasi (X1) dalam tes ini adalah 0,052413 yang berarti bahwa keputusan investasi mempunyai pengaruh positif terhadap nilai perusahaan.

3) Koefisien regresi return on asset (X2) dalam tes adalah 1,912066 yang berarti return on asset memiliki pengaruh positif terhadap nilai perusahaan.

4) Koefisien regresi return on equity ((X3)pada pengujian -0.203046 berarti return on equity berpengaruh negatif terhadap nilai perusahaan.

\section{b. Uji t (Parsial)}

Uji t ( uji secara parsial ) digunakan untuk menunjukkan apakah variabel independen secara individu mempunyai pengaruh yang terhadap variabel dependen.

Dasar Pengambilan keputusan :

Jika signifikan $>0,05$ (t hitung $<\mathrm{t}$ tabel $)$ maka Ha ditolak

Jika signifikan $<0,05$ ( $\mathrm{t}$ hitung $<\mathrm{t}$ tabel $)$ maka Ha diterima

\section{Hasil Uji t (Parsial )}

Dependent Variable: PBV

Method: Panel Least Squares

Date: 03/06/16 Time: 16:19

Sample: 20102014

Periods included: 5

Cross-sections included: 20

Total panel (balanced) observations: 100

\begin{tabular}{lrrrl}
\hline \hline Variable & \multicolumn{2}{c}{ Coefficient Std. Error } & t-Statistic & Prob. \\
\hline \hline C & 1.507765 & 0.853984 & 1.765567 & 0.0806 \\
PER & 0.052413 & 0.025275 & 2.073670 & 0.0408 \\
ROA & 1.912066 & 0.751385 & 2.544723 & 0.0125 \\
ROE & -0.203046 & 0.100005 & -2.030355 & 0.0451 \\
& 0.106208 & Mean dependent var & 2.232400 \\
\hline \hline R-squared & 0.078277 & S.D. dependent var & 3.347260 \\
Adjusted R-squared & & & & \\
S.E. of regression & 3.213584 & Akaike info criterion & 5.211829
\end{tabular}




\begin{tabular}{llll} 
Sum squared resid & 991.4036 & Schwarz criterion & 5.316035 \\
Log likelihood & -256.5914 & Hannan-Quinn criter. & 5.254003 \\
F-statistic & 3.802524 & Durbin-Watson stat & 1.365708 \\
Prob(F-statistic) & 0.012655 & & \\
\hline
\end{tabular}

Sumber : Data diolah dengan menggunakan Eviews 7.2

Berdasarkan hasil uji t diatas diperoleh hasil sebagai berikut :

1) Hipotesis Pertama $(\mathrm{H} 1)$

2) Keputusan investasi (PER) mempunyai signifikansi 0,012655 $<0,05$ dan $t$ hitung $2.073670>$ tabel 1,9850, maka ( $\mathrm{H} 1$ diterima).

3) Hipotesis kedua $(\mathrm{H} 2)$

4) Return on Asset (ROA) mempunyai signifikansi 0,012655 <0,005 dan t hitung 2,544723 > t tabel 1,9850 kemudian ( $\mathrm{H} 2$ diterima).

5) Hipotesis ketiga $(\mathrm{H} 3)$ mempunyai signifikansi $0,012655<0,005$ dan $t$ hitung2,030355 > t tabel 1,9850 kemudian (H3 diterima).

\section{c. Uji F simultan}

Tabel 4.10

Hasil Uji F ( Simultan )

Dependent Variable: PBV

Method: Panel Least Squares

Date: 03/06/16 Time: 16:19

Sample: 20102014

Periods included: 5

Cross-sections included: 20

Total panel (balanced) observations: 100

\begin{tabular}{lcccc}
\hline \hline Variable & \multicolumn{2}{l}{ Coefficient Std. Error } & t-Statistic & Prob. \\
\hline \hline C & 1.507765 & 0.853984 & 1.765567 & 0.0806 \\
PER & 0.052413 & 0.025275 & 2.073670 & 0.0408 \\
ROA & 1.912066 & 0.751385 & 2.544723 & 0.0125 \\
ROE & -0.203046 & 0.100005 & -2.030355 & 0.0451 \\
& & & & \\
\hline \hline R-squared & 0.106208 & Mean dependent var & 2.232400 \\
Adjusted R-squared & 0.078277 & S.D. dependent var & 3.347260
\end{tabular}




\begin{tabular}{llll} 
S.E. of regression & 3.213584 & Akaike info criterion & 5.211829 \\
Sum squared resid & 991.4036 & Schwarz criterion & 5.316035 \\
Log likelihood & -256.5914 & Hannan-Quinn criter. & 5.254003 \\
F-statistic & 3.802524 & Durbin-Watson stat & 1.365708 \\
Prob(F-statistic) & 0.012655 & & \\
\hline
\end{tabular}

Sumber : Data diolah dengan menggunakan Eviews 7.2

Sedangkan $\mathrm{F}$ tabel yang diperoleh adalah sebagai berikut

Berdasarkan hasil uji $F$ di atas diperoleh bahwa keputusan investasi (PER), return on asset (ROA), return on equity (ROE) memiliki signifikansi 0,012655 <0,05 dengan $F$ hitung 3,802524> tabel F 2,70 maka H4 diterima. Ini berarti bahwa keputusan investasi, return on asset dan return on equity secara simultan memiliki pengaruh signifikan terhadap nilai perusahaan

\section{E. KESIMPULAN}

\section{Kesimpulan}

Berdasarkan hasil analisis data tentang pengaruh keputusan investasi, return on asset, dan return on equity sebagian atau simultan terhadap nilai perusahaan pada Bank (Perbankan) perusahaan yang terdaftar di Bursa Efek Indonesia periode 2010-2014, diperoleh kesimpulan sebagai berikut:

1. Pengaruh Keputusan Investasi Terhadap Nilai Perusahaan dapat dilihat dari hasil perhitungan t. Variabel keputusan investasi menunjukkan bahwa nilai $\mathrm{t}$ hitung > ttabel $(2,073670>1,9850)$ dengan nilai signifikansi $0,012655<0,05$ maka $\mathrm{H} 1$ diterima,dengan demikian Keputusan Investasi berpengaruh positif dan signifikan terhadap Nilai Perusahaan

2. Pengaruh Return On Asset Terhadap Nilai Perusahaan dilihat dari hasil perhitungan $t$. Return on asset variable menunjukkan bahwa nilai thitung $>$ ttabel $(2,544723>1,9850)$ dengan nilai signifikansi 0,012655 < maka H2 diterima, dengan demikian Return On Asset berpengaruh positif dan signifikan terhadap Nilai Perusahaan

3. Pengaruh Return On Equity Terhadap Nilai Perusahaan dilihat dari hasil perhitungan $t$. Variabel return on equity menunjukkan bahwa nilai $t{ }^{\text {hitung }}>t^{\text {tabel }}$ (2,030355> 1,9850) dengan nilai signifikansi 0,012655 <maka H3 diterima, sehingga menunjukkan ada pengaruh negatif yang signifikan (-) pada variabel nilai perusahaan, dengan demikian Return On Equity berpengaruh negatif dan signifikan terhadap Nilai Perusahaan

\section{Saran}

1. Lebih baik bagi bank (bank) untuk memperhatikan stabilitas profitabilitas dan membuat manajemen laba yang baik sehingga perusahaan dapat meningkatkan laba dalam mencapai nilai perusahaan, karena nilai perusahaan dipengaruhi oleh peningkatan laba.

2. Penelitian harus menggunakan variabel lain dalam studi selanjutnya seperti Return On Investment (ROI), Net Profit Margin (NPM), dan faktor-faktor lain untuk menghasilkan laba tinggi dan mengurangi risiko perusahaan dalam meningkatkan praktik nilai perusahaan yang sebenarnya. 


\section{DAFTAR PUSTAKA}

Abdul Kadim, K., \& Nardi Sunardi, S. (2018). Determinant Of Company's Likuidity And It's Implications On Financial's Performance Of Ritail Trade Company's In Indonesia At The Period Of 2008-2017. Global and Stockhastic Analysis, 5(7), 235-247.

Atmaja, Luke Setia. (2008). Teori \& Praktek dalam Manajemen Keuangan, Yogyakarta: CV ANDI.

Brigham, Eugene F dan Joel F. Houston. (2006). Dasar-dasar Manajemen Keuangan. Buku 1. Jakarta: Empat Salemba.

Brigham, Eugene F dan Philips R. Daves. (2006). Manajemen Keuangan Menengah. Edisi 9. Jakarta: Empat Salemba.

Dwi Prastowo. (2011). Analisis laporan keuangan. Edisi 3. Yogyakarta: Sekolah Tinggi Manajemen YKPN.

Dwi Sukirni, 2012. "Kepemilikan Manajerial, Kepemilikan Institusional, Kebijakan Dividen dan Analisis Kebijakan Hutang Nilai Perusahaan", Jurnal Analisis Akuntansi. Vol. 2, No. 1: $1-2$.

Fahmi, Irham. (2014). Keuangan dan Manajemen Keuangan Perusahaan. Jakarta: MitraWacana Media.

Gill, James. O dan Moira Chatton. (2008). Memahami Laporan Keuangan. PPM. Jakarta.

Harjito, Agus \& Martono (2013). Manajemen Keuangan (Edisi 2). Yogyakarta: EKONOMI.

Lesmana, R. (2016). Strategi Pemasaran Untuk Meningkatkan Penjualan Perumahan Di Green River City Bekasi (Studi Kasus Di PT. Artha Bangun Pratama). INOVASI Jurnal IImiah IImu Manajemen, 3(2), 40-59.

Lesmana, R. (2019). Pengaruh Kualitas Produk Dan Kualitas Pelayanan Terhadap Kepuasan Konsumen Pt. Radekatama Piranti Nusa. Jurnal Pemasaran Kompetitif, 2(2), 115-129.

Sartono, Agus. (2006). Manajemen Aplikasi Keuangan dan Agensi. Edisi ketiga. Yogyakarta: BPFE

Sugiyono. (2010). Metode Penelitian Kuantitatif, Kualitatif, dan R\&D. Bandung: Alfabeta.

Sunardi, N. (2017). Determinant of leverage and it's implication on company value of real estate and property sector listing in IDX period of 2011-2015. Man in India, vol: 97, issue : 24

Sunardi, N. (2019). Mekanisme Good Corporate Governance Terhadap Nilai Perusahaan Dengan Leverage Sebagai Variabel Intervening Pada Perusahaan Manufaktur Yang Terdaftar Di Bursa Efek Indonesia Tahun 2012-2018. JIMF (Jurnal IImiah Manajemen Forkamma), 2(3). 
Sunardi, N. (2019, January). Relevansi Struktur Kepemilikan Tentang Profitabilitas Dan Nilai Perusahaan (Studi pada Industri Manufaktur yang Terdaftar di Bursa Efek Indonesia Periode 2010-2017). In Proceedings (Vol. 1, No. 1).

Sunardi, N. S. N., Lesmana, R., \& Tumanggor, M. (2018). Implementasi Manajemen Dalam Meningkatkan Iman Dan Taqwa Masyarakat Dusun Panyeredan, Cimanggu, Cisalak, Subang-Jawa Barat. Jurnal Pengabdian Dharma Laksana, 1(1).

Sunardi, N., \& Hendarsah, D. (2019). Faktor-Faktor yang Mempengaruhi Laba dan Dampaknya pada Nilai Perusahaan (Studi Kasus Pada Perusahaan BUMN Bidang Kontruksi Yang Terdaftar Di Bursa Efek Indonesia tahun 2008-2017). Jurnal SEKURITAS (Saham, Ekonomi, Keuangan dan Investasi), 3(1), 1-21.

Sutrisno. (2012). Manajemen Keuangan, Teori, Konsep \& Aplikasi. Yogyakarta: EKONISIA.

Tambunan, Andy. (2007). Menilai Harga Wajar Saham. Jakarta: Elex Media Komputindo.

Wijaya, LRP dan Wawa, BA (2010). Keputusan Investasi, Keputusan Pendanaan dan Dividen Kebijakan Terhadap Nilai-Nilai Perusahaan. Purwokerto: Simposium Nasional Akuntansi XIII.

Wijaya, Tony. (2011). SPSS Penguasaan Cepat 19 untuk Penelitian \& Interpretasi Data Penelitian dan Skrip. Yogyakarta: Cahaya Astma. 